TITLE:

\title{
Note on Mature Female of Itoitantulus misophricola Huys, Ohtsuka and Boxshall, 1992 (Crustacea : Tantulocarida)
}

$\operatorname{AUTHOR}(\mathrm{S}):$

Ohtsuka, Susumu

\section{CITATION:}

Ohtsuka, Susumu. Note on Mature Female of Itoitantulus misophricola Huys, Ohtsuka and Boxshall, 1992 (Crustacea : Tantulocarida). PUBLICATIONS OF THE SETO MARINE BIOLOGICAL LABORATORY 1993, 36(1-2): 73-77

ISSUE DATE:

1993-03-30

URL:

http://hdl.handle.net/2433/176222

RIGHT: 


\title{
Note on Mature Female of Itoitantulus misophricola Huys, Ohtsuka and Boxshall, 1992 (Crustacea: Tantulocarida)
}

\author{
Susumu Ohtsuka \\ Fisheries Laboratory, Hiroshima University, 1294 Takehara-cho, Takehara, \\ Hiroshima 725, Japan
}

With Text-figures $1-2$

\begin{abstract}
A mature adult female of Itoitantulus misophricola Huys, Ohtsuka \& Boxshall, 1992 (Crustacea: Tantulocarida: Deoterthridae) is described for the first time from the host misophrioid copepod Misophriopsis okinawensis Ohtsuka, Huys, Boxshall \& Itô, 1992 collected off Okinawa, South Japan. The female contains 26 mature, spherical eggs of ca. $30 \mu \mathrm{m}$ in diameter in the trunk sac, and is characterized by the lack of an elongate neck region formed between the larval cephalon and the expanded trunk sac. Mature females of the families Basipodellidae, Deoterthridae and Doryphallopholidae possess a characteristic of the lack of an elongate neck region, whereas those of the families Microdajidae and Onceroxenidae, in particular, Microdajus spp., have a well-developed neck region.
\end{abstract}

Key words: Itoitantulus misophricola, Tantulocarida, Deoterthridae

\section{Introduction}

The small-sized ectoparasitic crustacean group Tantulocarida exclusively utilizes free-living crustaceans such as copepods (e.g., Becker, 1975), ostracods (Bradford \& Hewitt, 1980), isopods (e.g., Boxshall \& Lincoln, 1983), cumaceans (Bonnier, 1903), and tanaidaceans (e.g., Greve, 1965) as host. Over 20 species have been reported from subtidal to abyssal zones in the Atlantic and Indo-Pacific regions (see Huys, 1991). The hypothetical life cycle of Tantulocarida was clearly presented by Boxshall \& Lincoln (1987) and Huys (1991). The Tantulocarida has a single larval stage, which is often found free-living in sediments before attaching to a crustacean host (Huys, 1989, 1991; Huys, Andersen \& Kristensen, 1992). The female sloughs the larval pedigerous and abdominal somites and develops a sac-like trunk with eggs behind the larval cephalic shield. Females of the following 10 species have been described: Basipodella harpacticola Becker, 1975 and B. atlantica Boxshall \& Lincoln, 1983 (Basipodellidae); Coralliotantulus coomansi Huys, 1990 and Itoitantulus misophricola Huys, Ohtsuka \& Boxshall, 1992 (in Huys, Ohtsuka, Boxshall \& Itô, 1992) (Deoterthridae); Microdajus langi Greve, 1965 and M. gaelicus Boxshall \& Lincoln, 1987 (Microdajidae); Onceroxenus birdi Boxshall \& Lincoln, 1987 and O. curtus Boxshall \& Lincoln, 1987 (Onceroxenidae); Doryphallophora harrisoni (Boxshall \& Lincoln, 1987) (Doryphallophoridae); Cumoniscus kruppi Bonnier, 1903 (incertae sedis).

From Japan, Huys, Ohtsuka, Boxshall \& Itô (1992) first reported the tantulo-

Publ. Seto Mar. Biol. Lab., 36(1/2), 73-77, $1993 . \quad$ (Article 3) 
caridan Itoitantulus misophricola parasitic on the hyperbenthic misophrioid copepod Misophriopsis okinawensis Ohtsuka, Huys, Boxshall \& Itô, 1992. However, they described only the tantulus larva and immature male and female of 1 . misophricola. One of the host misophrioid copepods which were not examined in my previous work (Ohtsuka et al., 1992) was parasitized by a mature female of $I$. misophricola. The present paper describes the mature female of $I$. misophricola and compares it wtih other tantulocaridan females.

\section{Materials and Methods}

The host misophrioid copepod Misophriopsis okinawensis was collected from hyperbenthic water off Kume Island, Okinawa, South Japan (26 $17.9^{\prime} \mathrm{N}, 126^{\circ} 54.2^{\prime} \mathrm{E}$ ) on 23 May 1989 (local time 08240858) with an originally designed sledge-net (Ohtsuka et al., 1992; Huys, Ohtsuka, Boxshall \& Ito, 1992). Sampling gear and techniques and laboratory procedures have been described in detail elsewhere (Ohtsuka et al., 1992).

\section{Description}

Mature female of Itoitantulus misophricola (Figs. 1 \& 2)

The specimen was attached to the first endopod segment of the left maxilliped of a copepodid $\mathrm{V}$ of Misophriopsis okinawensis. The cephalic shield (Fig. 1, C) and the cephalic stylet (Fig. 1, CS) are as described for the tantulus larva (cf. Huys, Ohtsuka, Boxshall \& Itô, 1992, p. 880, Fig. 4B-G). The cephalic shield is $66 \mu \mathrm{m}$ long. The scar (Fig. 1, S) is anteroventrally located. The adult female lacks a long neck region formed between the larval cephalosome and the trunk sac. The trunk is posteriorly expanded to form an oval brood sac which is $274 \mu \mathrm{m}$ long. The trunk surface is smooth and devoid of wrinkles such as are found in the immature female of Coralliotantulus coomansi by Huys (1990b) and Onceroxenus curtus by Boxshall \& Lincoln

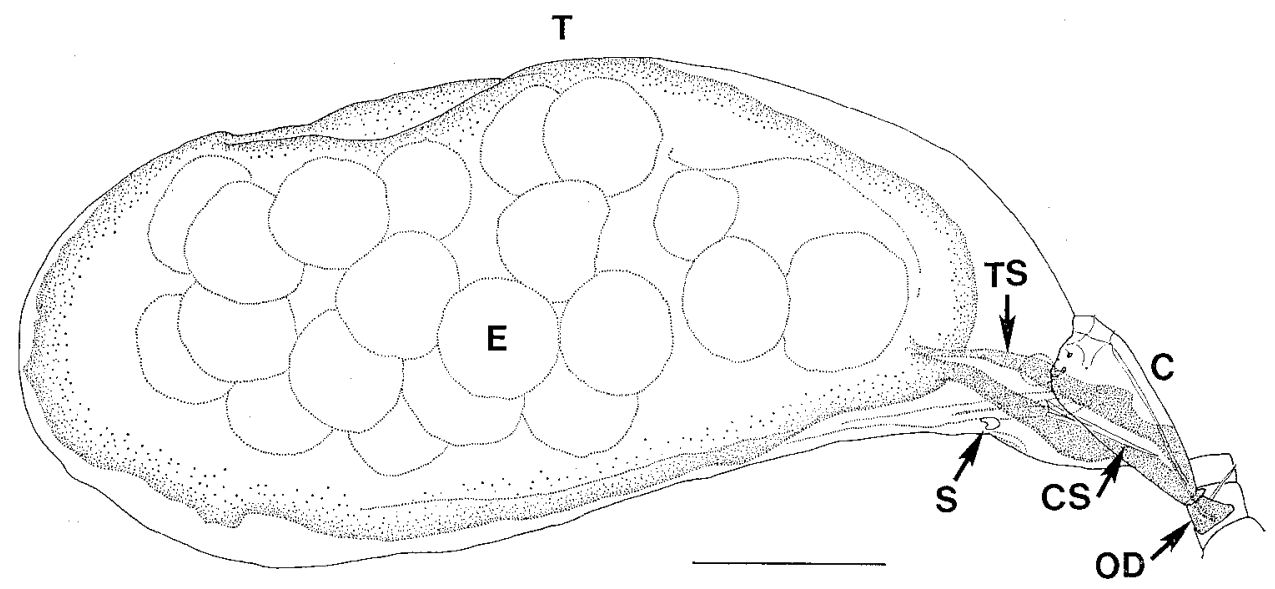

Fig. 1. Itoitantulus misophricola Huys, Ohtsuka \& Boxshall, 1992. Mature female. Habitus, lateral view. G: cephalic shield; T: trunk; S: scar; OD: oral disc; TS: tubular structure; CS: cephalic stylet; E: egg. Scale bar $=50 \mu \mathrm{m}$. 
(1987) (Fig. 2A). The translucent anterior part of the trunk is empty (Fig. 2B). The brood sac is connected with the oral disc by a tubular internal structure (Fig. 1, TS) and contains 26 spherical, mature eggs of about $30 \mu \mathrm{m}$ in diameter (Fig. 1, E). The eggis are medially located within an inner cellular sac. Eggs at the multi-celled stage are clearly visible in the sac.

No gonopore like that observed in a fully grown female Microdajus langi with SEM (Huys, 1991) was discernible with LM, but approximately $20 \mu \mathrm{m}$ long, postero-ventral slit-like structure is present.

\section{Discussion}

The structures of the neck regions of 9 species belonging to the five recognized families of the Tantulocarida show great variability. Microdajus langi, M. gaelicus, Onceroxenus birdi, and $O$. curtus have a long, folded and twisted neck region. On the other hand, Basipodella harpacticola, B. atlantica, Coralliotantulus coomansi and Itoitantulus misophricola are devoid of such a neck. Mature females of the four species with the neck, in particular Microdajus spp., are relatively large-sized, ca. $500-900 \mu \mathrm{m}$ in total
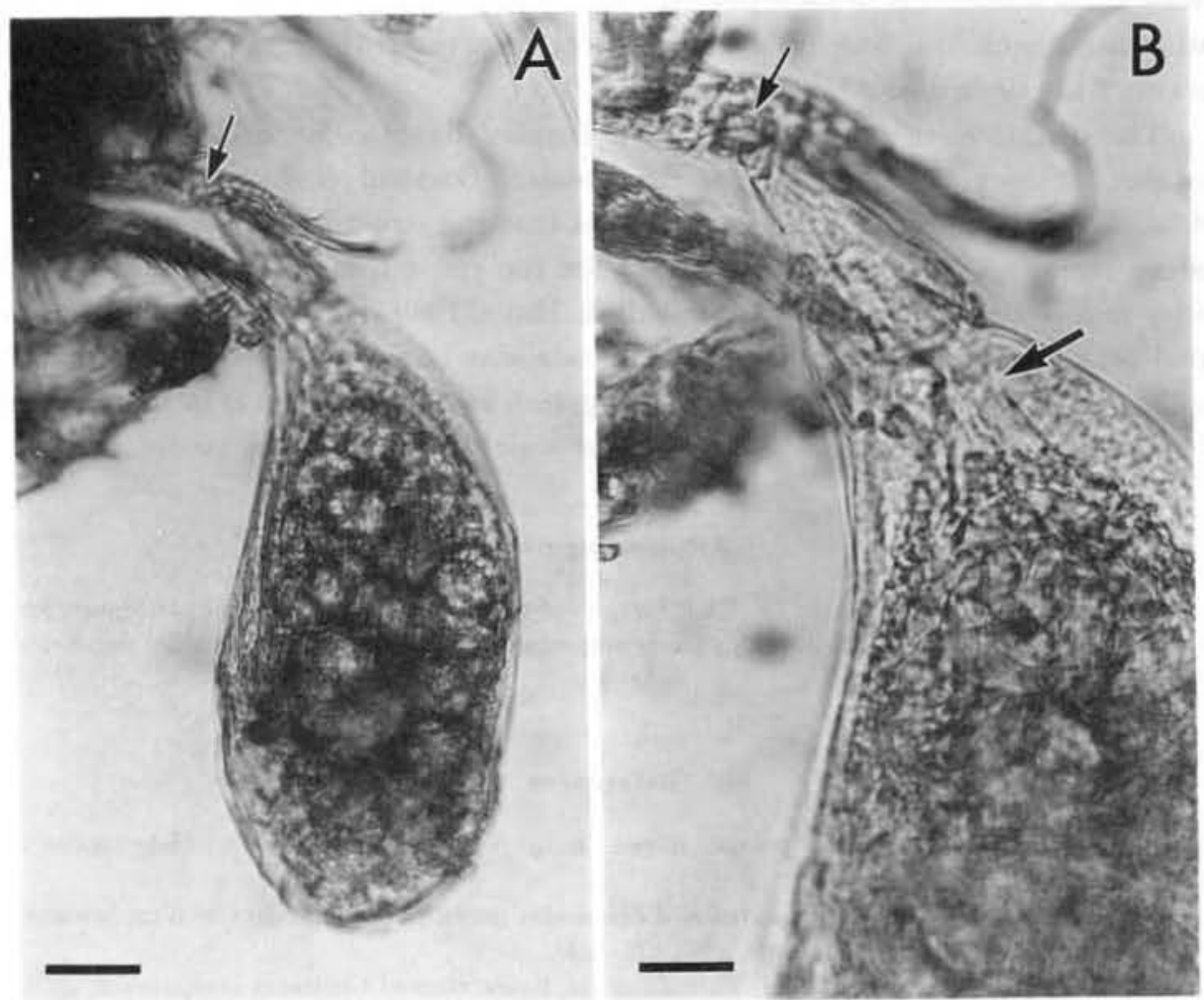

Fig. 2. Itoitantulus misophiricola Huys, Ohtsuka \& Boxshall, 1992. Mature female. A. Habitus, lateral view, attachment site indicated by an arrow, scale bar $=40 \mu \mathrm{m}$; B. Cephalic shield and anterior portion of trunk, attachment site indicated by a small arrow and tubular structure by a large arrow, scale bar $=20 \mu \mathrm{m}$. 
length, and parasitize deep-sea tanaidaceans. Mature females of the species without a neck are small, measuring about $100-300 \mu \mathrm{m}$ in total length, and infest small copepods. Since only immature females of Doryphallophora harrisoni were reported (cf. Boxshall \& Lincoln, 1987), there remains a possibility that mature females of this species have a neck, because $D$. harrisoni parasitizes relatively large-sized, asellote isopods.

In $M$. langi with a long neck region, the brood sac is very large, containing up to 100 eggs of $33^{\circ} \mu \mathrm{m}$ in diameter (Greve, 1965; Grygier \& Sieg, 1988). M. gaelicus also has more than 100 eggs in the trunk sac (Boxshall \& Lincoln, 1987). Eggs of I. misophricola are of nearly the same size as those of $M$. langi, though the number of eggs is 26 in $I$. misophricola and much fewer than in Microdajus spp. Large-sized, fully developed, adult females of Microdajus spp. seem to interfere with the behaviors of their hosts (cf. Boxshall \& Lincoln, 1987). However, tantulocaridans must obtain their nourishment from "living" host crustaceans while they attach to the hosts. Therefore, tantulocaridans parasitic on small-sized copepods may not have a developed, elongate neck region and may produce fewer eggs witin the relatively small trunk sac than tantulocaridans parasitic on tanaidaceans and isopods, which can be interpreted as an adaptation to their parasitic life on tiny hosts. It is likely that the folded and twisted neck functions as shock absorber to prevent the large brood sac of the parasite from detaching from the host.

The diagnoses of the tantulocaridan families have so far been given only for tantulus larvae and males but not for females (Boxshall \& Lincoln, 1987, Huys, 1990a, 1991). The present finding suggests that the structure of the neck region of mature females is one of key characters for the respective family. The most primitive family Basipodellidae (cf. Boxshall \& Huys, 1989, Huys, 1990a) has no developed neck while the advanced family Microdajidae has an extremely elongated neck region. Considering these points, the elongation of a neck region is in more advanced state, and might have evolved in groups which infest deep-sea tanaidaceans.

\section{Acknowledgnents}

I express my sincere thanks to Dr. M.J. Grygier of the Seto Marine Biological Laboratory for his critical reading of the manuscript. This study was supported in part by a grant by the Research Institute of Marine Invertebrates.

\section{References}

Becker, K.-H. 1975. Basipodella harpacticola n. gen., n. sp. (Grustacea, Copepoda). Helgoländer wiss. Meeresunters., $27: 96-100$.

Bonnier, J. 1903. Sur deux types nouveaux d'Epicarides parasites d'un Cumacé et d'un Schizopode. C.r. hebd. Séanc. Acad. Sci., Paris, 136: 102-103.

Boxshall, G.A. \& R.J. Lincoln. 1983. Tantulocarida, a new class of Crustacea ectoparasitic on other crustaceans. J. Crust. Biol., 3: 1-1€.

\& 1... 1987. The life cycle of the Tantulocarida (Crustacea). Phil. Tarns. R. Soc. Lond., B315: 267-303.

Bradford, J.M. \& G.C. Hewitt. 1980. A new maxillopodan crustacean, parasitic on a myodocopid 
ostracod. Crustaceana, 38: 67-72.

Greve, L. 1965. A new epicaridean from western Norway, parasite on Tanaidacea. Sarsia, 20: 1519.

Grygier, M.J. \& J. Sieg. 1988. Microdajus (Crustacea: Tantulocarida) parasitic on an Antarctic tanaidacean, and a range extension of $M$. langi Greve. J. nat. Hist., 22: 1495-1505.

Huys, R. 1989. Dicrotrichura tricincta gen. et spec. nov.: a new tantulocaridan (Grustacea: Maxillopoda) from the medditerranean deep sea off Corsica. Bijdr. Dierk., 59: 243-249.

1990a. Campyloxiphos dineti gen. et spec. nov. from off Namibia and a redefinition of the Deoterthridae Boxshall and Lincoln (Crustacea: Tantulocarida). J. nat. Hist., 24: 415-432.

-2. 1990b. Coralliotantulus coomansi gen. et sp. n.: first record of a tantulocaridan (Crustacea: Maxillopoda) from shallow subtidal sands in tropical waters. Stygologia, 5: 183-198.

- 1991. Tantulocarida (Crustacea: Maxillopoda): a new taxon from the temporary meiobenthos. P.S.Z.N.I: Mar. Ecol., 12: 1-34.

—_- S. Ohtsuka, G.A. Boxshall \& T. Itô. 1992. Itoitantulus misophricola gen. et sp. nov.: first record of Tantulocarida (Grustacea: Maxillopoda) in the North Pacific region. Zool. Sci., 9: 875-886.

, P.F. Andersen \& R.M. Kristensen. 1992. Tantulacus hoegi gen. et sp. nov. (Tantulocarida: Deoterthridae) from the meiobenthos of the Faroe Bank, North Atlantic. Sarsia, 76: 287-297.

Ohtsuka, S., R. Huys, G.A. Boxshall \& T. Itô. 1992. Misophriopsis okinawensis sp. nov. (Crustacea: Copepoda) from hyperbenthic waters off Okinawa, South Japan, with definitions of related genera Misophria Boeck, 1864 and Stygomisophria gen. nov. Zool. Sci., 9: 859-874.

Note in proof. Huys, Boxshall \& Lincoln (in press. The tantulocaridan life cycle: the circle closed? J. Grust. Biol., 13(3)) first found two life cycles in the Tantulocarida, namely, parthenogenetic and sexual pathways. Since the sexual female is a free-living stage (Huys et al., in press), the female of Itoitantulus misophricola described here is parthenogenetic. 